\title{
Development of a Laboratory Procedure to Evaluate the Consolidation Potential of Soft Contaminated Sediments
}

\begin{abstract}
Consolidation settlement of non-aqueous phase liquid (NAPL) contaminated sediments may trigger NAPL mitigation. The consolidation potential and resulting NAPL mobilization of the sediments should be evaluated in the laboratory; however, due to the highly compressible and weak nature of riverbed sediments, it is usually not possible to conduct conventional consolidation tests on sediment specimens. In this study, a triaxial setup was modified to work effectively under low stresses. Kaolinite was used to represent the soil solid phase and Soltrol 130 (a type of mineral oil) was used to represent the NAPL. Both oil-wetted and water-wetted regimes were analyzed. Hexane Extraction and moisture content tests results confirmed the final fluid amounts in the specimen obtained by measuring the effluent volume during consolidation. The results of the tests show that approximately $0.1 \mathrm{~g}$ of NAPL per $1 \mathrm{~g}$ of soil solids is unlikely to be mobilized by consolidation. The developed procedure could also be employed to define the mobile and immobile fractions of NAPL and the expected compression of contaminated sediments. The volume of NAPL in excess of the retained residual can be used to design NAPL collection systems or to size layers of NAPL sorbent materials such as organo-clays.
\end{abstract}

KEYWORDS: contamination, consolidation, kaolinite, NAPL, sediments

$\begin{aligned} & \text { Nomenclature } \\ & \mathrm{C}_{\mathrm{c}}=\text { Compression index } \\ & \mathrm{e}_{0}=\text { Initial void ratio } \\ & \mathrm{K}_{0}=\text { Lateral earth pressure coefficient at rest } \\ & \mathrm{K}_{\text {active }}=\text { Active lateral earth pressure coefficient } \\ & \mathrm{LL}=\text { Liquid limit } \\ & \mathrm{S}_{\mathrm{NAPL}}=\text { NAPL saturation ratio } \\ & \mathrm{V}_{\mathrm{NAPL}}=\text { Volume of NAPL } \\ & \mathrm{V}_{\text {Fluid }}=\text { Total volume of pore fluids } \\ & \mathrm{W}_{\mathrm{NAPL}}=\text { Weight of NAPL } \\ & \mathrm{W}_{\text {Solids }}=\text { Weight of soil solids } \\ & \sigma_{H}^{\prime}=\text { Horizontal effective stress } \\ & \sigma_{v}^{\prime}=\text { Vertical effective stress } \\ & \pi=\text { Plasticity index } \\ & \theta_{\mathrm{NAPL}}=\text { Volumetric NAPL content } \\ & \theta_{\text {water }}=\text { Volumetric water content }\end{aligned}$

Manuscript received December 10, 2010; accepted for publication June 9, 2011; published online July 2011.

${ }^{1}$ Graduate Research Assistant, Univ. of Texas at Austin, 1 University Station C1792, Austin, TX 78712-0273. (Corresponding author), e-mail: mberten@mail.utexas.edu

${ }^{2}$ Brunswick-Abernathy Regents Professor in Soil Dynamics and Geotechnical Engineering, Univ. of Texas at Austin, 1 University Station C1792, Austin, TX 78712-0273.

${ }^{3}$ Ph.D., Assistant Professor, Dept. of Civil, Architectural, and Environmental Engineering, Univ. of Texas at Austin, Austin, TX 78712-0273.

${ }^{4}$ Bettie Margaret Smith Chair of Environmental Health Engineering, Dept. of Civil, Architectural, and Environmental Engineering, Univ. of Texas at Austin, TX 78712-0273.

$$
\begin{aligned}
\varphi & =\text { Total stress friction angle } \\
\varphi^{\prime} & =\text { Effective stress friction angle }
\end{aligned}
$$

\section{Introduction}

Consolidation testing of non aqueous phase liquid (NAPL) contaminated sediments is challenging since they usually are fine grained low strength media with very high water contents. Although contaminants may be contained in sediments effectively by using various remediation methods, there is always a concern that these contaminants may mobilize and migrate into the overlying water. A cover or cap of clean sediment on top of the contaminated sediment is one approach used to try to reduce this migration (Zeman 1994). However, adding a sand layer on top of a soft sediment will cause consolidation settlement that might lead to mobilization of the NAPL (Azcue et al. 1998). Therefore, it is important to determine the consolidation properties of the sediment to try to predict both amount and properties of the expelled NAPL due to the added load. The consolidation properties of sediments can be evaluated by laboratory tests; however, these tests are challenging mainly because these sediment specimens are very soft and they may contain contaminants which require special care. Usually sediments have very high fluid content, which makes preparing a laboratory sample almost impossible. The focus of this work is to develop a procedure to measure consolidation properties of these soft NAPL contaminated sediments and simultaneously measure the amount and quality of the water and/or NAPL that might be expelled.

Steward (2007) introduced a new method for specimen preparation of undisturbed NAPL contaminated sediments and 
conducted consolidation tests using a triaxial setup. Initial NAPL saturation of the test samples changed between $0 \%-38 \%$. Effluent was collected in bladder accumulators. NAPL mobilization was observed in two of the nine specimens tested. Moretti (2008) conducted similar tests on NAPL contaminated sediments. The results indicated that consolidation may mobilize the NAPL in sediments. Steward (2007) and Moretti (2008) worked on field samples which varied significantly in terms of the soil type and pore fluid constituents. This heterogeneity made it difficult to derive general conclusions on the consolidation behavior.

Thornley (2006) tested oil contaminated sediments by mixing kaolinite and bentonite with oil at low oil/water volume ratios. The sediment slurries were tested in a modified Rowe Cell. The results showed that the addition of oil had a minor effect on the consolidation behavior when compared to the results of the tests on clean kaolinite and bentonite slurries. The results showed that oil mobilization can occur due to the consolidation of specimens.

Ma et al. (2010) conducted column tests to evaluate the consolidation of very soft sediments and the effect of consolidation on the expulsion of contaminated pore fluid. The column test had certain advantages such as being easy to set up and an inexpensive apparatus. The major disadvantages were the following: the diameter to height ratio of the specimens was very low resulting in high bias in the results due to wall friction. In addition, the fluid pressures in the specimen could not be controlled, and the volume of the effluent was not known.

Imai (1979), Imai et al. (1984), and Sridharan and Prakash (1999) conducted seepage consolidation tests on very soft soils. In a seepage consolidation test, the specimen was consolidated in a tube under a differential hydraulic head applied across the specimen. This type of consolidation test is very useful for testing very soft clean specimens although the applied differential head is typically much larger than would be applied under self-weight consolidation or with a thin sand cap and unrealistic amounts of NAPL may be mobilized by this head difference. Centrifuge testing is another common way of testing very soft sediments (Moo-Young et al. 2003; Robinson et al. 2003). The major concern with running centrifuge tests is being able to appropriately model low load consolidation NAPL and water behavior from the response at the varying accelerations.

Lee and Fox $(2008,2009)$ and Lee et al. (2009) conducted consolidation tests to investigate the effect of consolidation on solute transport. They concluded that consolidation can make the solute transport faster. In these tests, they used a miscible tracer to detect the pore fluid mobilization.

Contaminants may exist in the pore spaces at different saturation ratios and they may be miscible or immiscible with the pore water. Variation in the pore fluid may influence the physicochemical structure of the soil and affects its consolidation and strength properties. The influence of pore fluid on the characteristics of soils was investigated in several studies. Mesri and Olson (1971) calculated coefficients of permeability of kaolinite, illite, and smectite with different pore fluids. Permeability values were back calculated from the consolidation data by using Terzaghi's theory of one-dimensional consolidation. The results indicated that permeabilities were highest for non-polar pore fluids and lowest for water (high dielectric constant fluid). Acar and
Olivieri (1989) conducted hydraulic conductivity tests on compacted kaolinite specimens. In this study, it was observed that when organic fluids were permeated through the specimen, the hydraulic conductivity of soils changed. Anandarajah and Zhao (2000) investigated the effect of different pore fluids on the strength of kaolinite.

Olson and Mesri (1970) conducted one dimensional consolidation tests on kaolinite slurries as well as illite and smectite slurries. The specimens included one-phase pore fluids, which were water, carbon tetrachloride, and ethyl alcohol. The results showed that the consolidation behavior of kaolinite was governed mainly by the mechanical factors rather than physico-chemical effects. The mechanical factors were defined as the strength, flexibility, and surface friction of the soil particles. In addition, the compressibility of kaolinite with carbon tetrachloride and ethyl alcohol was different than the compressibility of water saturated samples.

The objective of this study is to develop a testing system to evaluate the consolidation potential of contaminated sediments at various oil saturation ratios. A regular oedometer consolidation test setup has certain disadvantages when used for testing soft contaminated sediments. Some of these limitations are: an accurate assessment of the amount of the effluent fluid is not possible; it does not allow application of pore pressures which can help simulate the field stress conditions; wall friction that can constrain the movement of the soil nest to the ring. In this study, a modified triaxial set up was used for consolidating soft sediments. The triaxial apparatus provided separate applications of vertical, horizontal, and pore pressures which ensured that the stress conditions in the field were simulated more accurately. Several modifications were made to the standard triaxial setup, specimen preparation and testing procedures so that the testing worked efficiently under low effective stresses and the expelled fluid could be collected for further testing. In addition, a laboratory preparation method for controlled NAPL contaminated sediment specimens at high fluid contents was developed. Finally, using the specimen preparation procedure and the modified triaxial setup, consolidation tests were successfully conducted on sediments at $0 \%-100 \%$ oil saturation ratios.

\section{Test Apparatus}

A triaxial setup has certain advantages over a conventional consolidation device. The apparatus allows vertical and horizontal stresses to be applied independently to let the specimen consolidate under anisotropic conditions. Pore pressures can be controlled to better represent the field conditions. In addition, the soil specimen is confined by a very soft membrane so that side frictions are eliminated to a great extent.

To adapt a conventional triaxial setup for consolidation of very soft contaminated sediments, several modifications were implemented. The loading system in a regular triaxial setup is designed to apply displacements at a constant rate. However, in a consolidation test, it is important to load a specimen in load-control conditions. To apply a constant load on the specimen, an air piston was attached at the top of the triaxial frame. The maximum pressure that the air piston can apply is $1034 \mathrm{kPa}$. A load cell was attached in between the air piston and the triaxial piston. The load cell had 

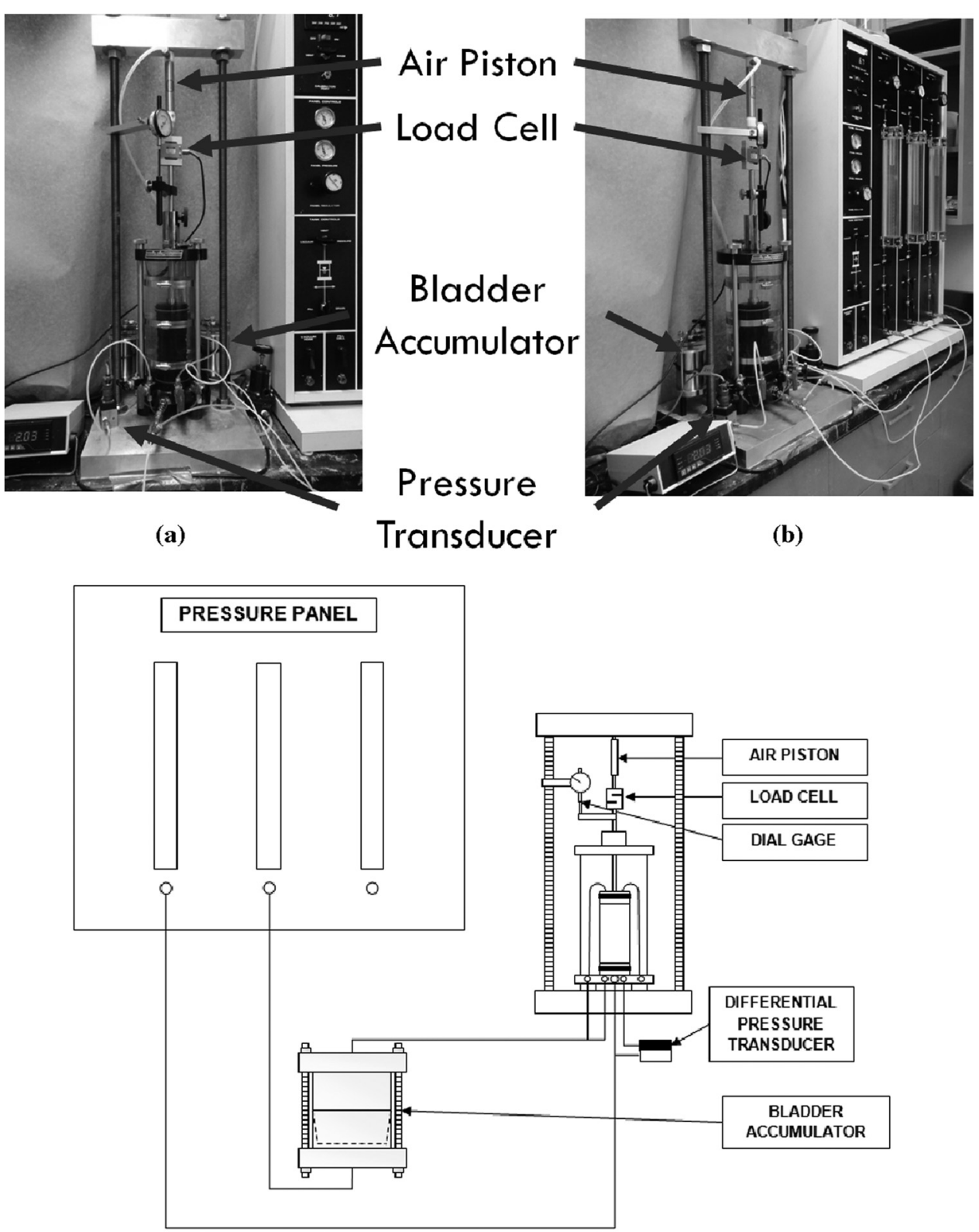

(c)

FIG. 1-( $a$ and b) Pictures and (c) schematic of final apparatus.

a maximum capacity of $11.3 \mathrm{~kg}$. The precision of the load cell was $\pm 0.005 \mathrm{~kg}$.

The confining pressure around the specimen was provided by using pressure regulators. The selected pressure regulators should have a low pressure range but should reach pressures up to the maximum required cell pressures. The pressure regulators had maximum output capacity of $69 \mathrm{kPa}$.

In a typical pressure panel, burettes are filled with water to capture the volume change in the specimen or the cell. When the applied pressure needs to be increased, air pressure is applied at the top of the water column in the burettes. However, the height of water in the burettes will create an additional stress and this stress will add to the applied air pressure. Since the pressures dealt with in a regular triaxial shear strength tests are reasonably high, this addi- tional water pressure is usually ignored. In a typical pressure panel with a burette length of $30 \mathrm{~cm}$, applied pressures can be off by as much as $2.76 \mathrm{kPa}$ from the pressure panel reading depending on the water level in the burette and the vertical location of the specimen relative to the burette. When testing near-surface sediments, where in situ effective stresses are fairly low, a $2.76 \mathrm{kPa}$ difference in applied effective stress would create a significant difference in the consolidation behavior. To overcome this problem, differential pressure transducers were connected at the bottom of the specimen and the cell. It is important that the pressure transducers are connected at the same height as the specimen and the cell. The differential pressure transducers had a maximum pressure limit of $86 \mathrm{kPa}$.

In a typical triaxial test in which the pore fluid is expected to be water only, latex membranes are preferred. However, 
contaminants in soil pores can react with the latex membrane and disintegrate it over the time of a consolidation tests (one test can take few weeks). Therefore, neoprene membranes were used for these tests since neoprene is non-reactive with most contaminants. In addition, the effluent tubing should be non-absorptive. Teflon tubing was used to overcome this problem.

Bladder accumulators were used in the setup to keep the effluent separated from the pressure panel and to avoid contaminants reaching the panel. The effluent goes into the bladder accumulator and pushes clean water out of the other half of the bladder into the pressure panel. The bladder accumulators help collect the contaminants for further analysis. The bladder is made of a non-reactive material; however, it is gas permeable.

A schematic of the final testing apparatus is shown in Fig. 1. The vertical displacements are recorded with a dial gage or an LVDT, which is placed on a plastic arm attached to the triaxial piston. The volume change in the cell and specimen was measured from the change in the volume of water in the burettes of the pressure panel.

\section{Materials}

While preparing laboratory specimens, Soltrol 130 Isoparaffin solvent was used to represent the NAPL phase in samples. Soltrol 130 is similar to a middle distillate such as diesel or kerosene. The properties of Soltrol 130 can be found in Table I. Because Soltrol 130 is transparent and hard to identify when it is with water, it was dyed with Sudan IV which is a fat soluble, red-colored dye. In all specimens, de-aired tap water was used as the water in the pore fluid. The samples very prepared by hand mixing (Fig. 2). Pure Georgia kaolinite was used to represent the sediment. The properties of kaolinite were well-defined in geotechnical practice so that kaolinite provided a well-defined boundary for the soil phase. Steward (2007) and Moretti (2008) performed triaxial consolidation tests on the actual NAPL contaminated sediments. The results indicated that it was complicated to characterize the NAPL

TABLE 1-Properties of Soltrol 130.

\begin{tabular}{lc}
\hline & Soltrol 130 Isoparaffin Solvent \\
\hline Boiling point & $181-209^{\circ} \mathrm{C}$ \\
Specific gravity & 0.762 at $15.6^{\circ} \mathrm{C}$ \\
Viscosity & $1.55 \mathrm{cSt} @ 38^{\circ} \mathrm{C}$ \\
Vapor pressure & $1.5 \mathrm{~mm} \mathrm{Hg} @ 38^{\circ} \mathrm{C}$ \\
\hline
\end{tabular}

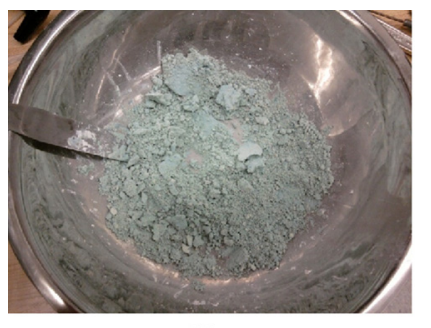

(a)

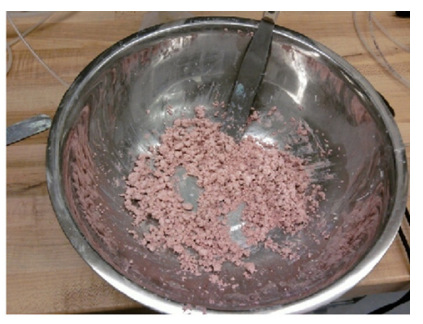

(b)

FIG. 2-The soil specimen after kaolinite was mixed with (a) Soltrol 130 and (b) Soltrol 130 and water. behavior due to the variation of the soil properties. Therefore, this research focused on using a uniform soil phase. By doing so, other factors influencing the NAPL behavior can be investigated.

\section{Preliminary Tests}

\section{Breakthrough Pressure Measurement}

After making the above-mentioned modifications, to ensure the breakthrough pressure was insignificant and water and oil could drain out the system freely as separate phases, the flow of oil through water-saturated porous stone, filter paper and the tubing system was evaluated. To measure the breakthrough pressure, one end of a pressure line was connected to the bottom of the pedestal and the other end was placed vertically open to the atmosphere. At the beginning, the triaxial cell was filled with Soltrol 130 up to the top of the filter paper (Fig. 3(a) and 3(c)). At this condition, applied breakthrough pressure was 0 . The water level in the pressure line on the side which was open to the atmosphere was at the same level with the top of the filter paper. Mineral oil was slowly added in to the cell and the height of the water in the tube was observed.

Figure $3(b)$ and $3(d)$ shows that when mineral oil level is approximately $28 \mathrm{~mm}$ above the filter paper, the water level on the other side of the line increases significantly. This indicates that mineral oil penetrated into the water-saturated filter paper and porous stone system and pushed up the water on the other side of the line. The result ensures that the breakthrough pressure of mineral oil through the water saturated system is less than $0.21 \mathrm{kPa}$.

\section{Hexane Extraction Procedure}

The NAPL and water contents of samples after testing were measured with the moisture content (ASTM D2216-10 2010) and a test for hexane extractible materials (U.S. Environmental Protection Agency 1998). After the consolidation test is finished, the test specimen was cut into six slices. From each slice two samples were taken. The first sample was placed into an oven for fluid content test (NAPL and water). Moisture content was measured by the difference in total evaporation during drying at $105^{\circ} \mathrm{C}$ and drying to complete elimination of the NAPL (volatile in this case). The NAPL content of that slice was measured by performing the Hexane Extraction procedure. The water in the samples was removed by mixing the soil samples with Sodium Sulfate $\left(\mathrm{Na}_{2} \mathrm{SO}_{4}\right)$. Then, these samples were placed in thimbles and the soxhlet extractor and the samples were continuously mixed with hexane for 16 to $24 \mathrm{~h}$ to extract the NAPL. The fluid content measurement procedure was summarized in Fig. 4.

In Table II, the estimated volumetric fluid contents at the end of a consolidation test (calculated using the initial fluid content and the consolidation test data) are compared to those from moisture content and Hexane Extraction tests. In Table II, $\theta_{\mathrm{X}}$ represents the ratio of the volume of " $\mathrm{X}$ " to the total volume of the soil. NAPL saturation $\left(\mathrm{S}_{\mathrm{NAPL}}\right)$ is defined as

$$
\mathrm{S}_{\mathrm{NAPL}}-\frac{\mathrm{V}_{\mathrm{NAPL}}}{\mathrm{V}_{\text {Fluid }}}
$$






(a)

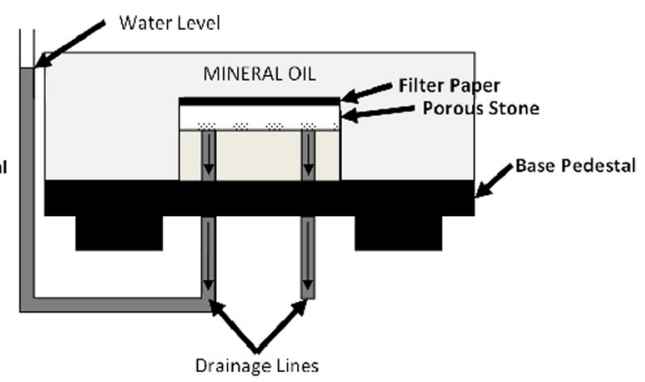

(b)



(c)

(d)

FIG. 3-Breakthrough test when the mineral oil level is ( $a$ and c) at the top of the filter paper (zero breakthrough pressure) and (b and d) slightly higher than the top of the filter paper (breakthrough pressure $\leq 0.21 \mathrm{kPa}$ ).

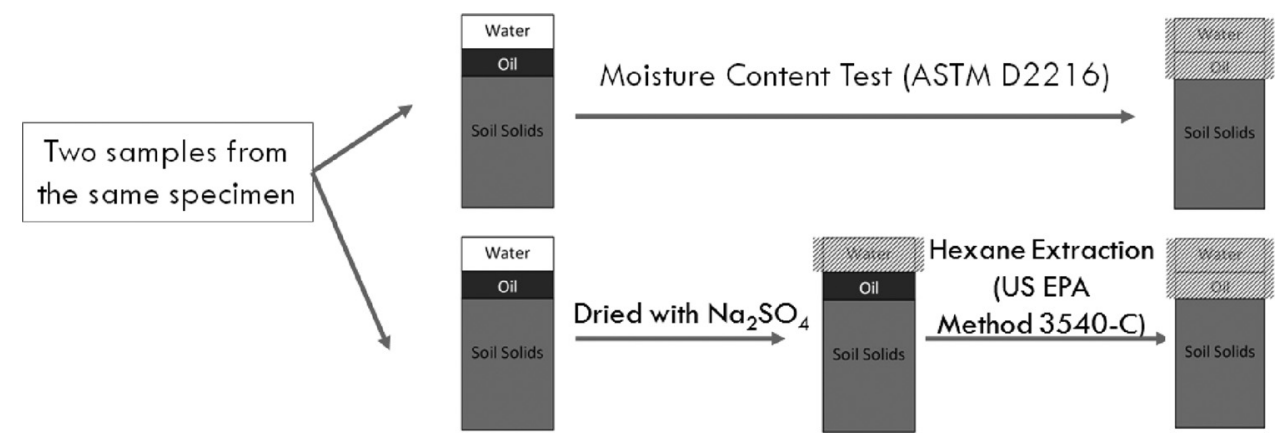

FIG. 4-Flowchart of the fluid content measurement.

TABLE 2 - Final fluid contents calculated from consolidation test readings, moisture content and hexane extraction tests.

\begin{tabular}{lcc}
\hline Hexane Extraction and Moisture Content Tests & Consolidation Test \\
\hline$\theta_{\text {water }}$ & $44 \%$ & $46 \%$ \\
$\theta_{\mathrm{NAPL}}$ & $12 \%$ & $14 \%$ \\
$\theta_{\text {total }}$ & $56 \%$ & $60 \%$ \\
$\mathrm{~S}_{\mathrm{NAPL}}$ & $21 \%$ & $23.0 \%$ \\
\hline
\end{tabular}

where:

$$
\begin{aligned}
\mathrm{V}_{\text {NAPL }} & =\text { Volume of NAPL } \\
\mathrm{V}_{\text {Fluid }} & =\text { Total Volume of Pore Fluids } .
\end{aligned}
$$

The fluid contents comparison in Table II implies that the amount of fluids after each consolidation stage can be successfully estimated by using the consolidation data.

\section{Sample Preparation}

El-Sherbiny (2006) placed kaolinite in a tub and filled the tub with water. The moisture content of kaolinite was measured at various depths after the primary consolidation was finished. By using the moisture content profile measured by El-Sherbiny 
(2006), the effective stress, moisture content profile was generated for the kaolinite. Then the moisture content of kaolinite was obtained for the imaginary samples which were located at depths of $0.9 \mathrm{~m}$ and $1.1 \mathrm{~m}$ below the mudline. In both cases, it was assumed that the depth of river was $3.3 \mathrm{~m}$ above the mudline. The in situ stresses (vertical and horizontal stresses, and pore pressure) were calculated for imaginary cases where the sample was located $0.9 \mathrm{~m}$ below the mudline for the clean sediments and $1.1 \mathrm{~m}$ below the mudline for the NAPL-contaminated sediments. The placement water content of the clean sediment samples was $90 \%$. The initial void ratio $\left(\mathrm{e}_{0}\right)$ for the clean sediments was 2.32 , while it was 2.05 for the NAPL contaminated sediments.

After determining the required fluid content for the corresponding $\mathrm{e}_{0}$, all the samples were mixed by hand in a bowl with a spatula (as seen in Fig. 2). Initial testing program showed that when the samples with oil and water were mixed at this $\mathrm{e}_{0}$, the maximum possible water saturation was $30 \%$. For any higher water saturation levels, the soil mixture became unstable and mineral oil floated out due to the buoyancy forces. Therefore, for specimens with oil and water pore fluid at water saturation higher than $30 \%$, the specimens were prepared at $30 \%$ water saturation and then water is flushed through the specimen to push out the NAPL until required water saturation is reached.

\section{Specimen Setup}

Before setting up the specimen, porous stones were saturated by either boiling them in water or placing them in an ultrasonic shaker for 20-25 min. Filter papers were saturated in a separate beaker. All the pressure lines were saturated with water before placing the soil mixture. Both the top cap and the bottom pedestal sides were greased to provide a better contact with the membrane. All samples had a diameter of $5.1 \mathrm{~cm}$ and a length of $10.2 \mathrm{~cm}$. A neoprene membrane was placed on the bottom pedestal. The membrane was sealed by using 3 o-rings. A saturated porous stone and a filter paper were placed inside the membrane on the bottom pedestal. A vacuum split mold was then placed around the membrane on the bottom pedestal and the top part of the membrane was flipped over the mold. Vacuum was applied between the mold and membrane for the membrane to take the form of the mold. While placing the soil mixture into the membrane, the main concern was to place the soil sample into the membrane at controlled NAPL and water contents at a certain initial void ratio. In addition, the sample should have been close to $100 \%$ saturation. The prepared soil mixture was placed in the membrane in several lifts. After each lift, soil was compacted by slightly tamping with a metal rod. By slight tamping, the fluid contents of the soil did not change. In addition, in the tests where the specimen had only one type of pore fluid (water or NAPL) after applying in situ stresses calculated for the imaginary case, the B-value was measured around 0.97 in all tests. This indicated that the specimens were very close to $100 \%$ saturation. Therefore, tamping was considered as the best method to place the soil into the membrane.

After placing the soil in the membrane, a filter paper, a porous stone and the top cap were placed on the top of the specimen. The membrane was rolled over the top cap and sealed with 3 o-rings. Pressure lines were connected to the top cap. For the clean sedi- ments samples the triaxial cell was filled with water while the top cap of the cell was still not in place. The vacuum split mold was carefully removed by using spatulas and tongs while the water was still in the cell. Specimen dimensions were assumed the same as the vacuum split mold. When the sample had NAPL, the vacuum split mold was easily removed. No bulging or sample deformation was observed due to the stress release. Specimen height and diameter were measured at several locations. Then the cell was assembled and filled with de-aired tap water. The triaxial piston was then placed in the divot on the top cap and locked without applying any pressure on the specimen.

\section{Flushing Stage}

As mentioned earlier, if $\mathrm{S}_{\mathrm{NAPL}}$ was required to be less than $70 \%$, the oil content decreased by pushing water from the top, which caused the NAPL to expel from the bottom. This stage is called the flushing stage. During the flushing stage, three lines connecting the pressure panel and the triaxial cell were used for pressure application: The first line was connected to the triaxial cell outside the specimen; the second line was connected directly to the top of the specimen; and the third line was connected to the bottom of the specimen through the bladder accumulator. Initially, the cell and the pore pressures were set to equal values. Then an extra pressure was applied to the top of the specimen. A hydraulic gradient was created due to the differential pressure at the top and the bottom of the specimen. The water was flushed through the specimen from the top and pushed the NAPL out from the bottom. The NAPL was collected in the top cell of the bladder accumulator. By doing so, NAPL saturation was gradually reduced since the NAPL in the specimen was replaced with water.

\section{Consolidation Test Procedure}

During the consolidation stage two lines were required between the panel and the triaxial cell. One of them was connected to the cell to control the cell pressure. The other line was connected to the bladder accumulator. The bladder accumulator was connected to the top and bottom of the specimen by using a t-connector. After the flushing stage was over, the pressures at the top and bottom of the specimen were set to the same value. Then cell pressure was increased to the effective stress required for the first consolidation stage. After that, pore pressures as well as cell pressure were increased simultaneously until required pore pressure was reached without changing the effective stresses during the process. The piston at the top was released and the vertical pressure was set to the uplift compensation. The specimen was consolidated under initial stresses calculated for the scenarios described previously.

During preliminary testing program, initially $\mathrm{K}_{0}$ was selected as $0.5 . \mathrm{K}_{0}$ is defined as the ratio of horizontal effective stress $\left(\sigma_{H}^{\prime}\right)$ to the vertical effective stress $\left(\sigma_{v}^{\prime}\right)$ on the soil specimen. However, when $\mathrm{K}_{0}$ was 0.5 or 0.6 , the sample failed during one of the consolidation stages. The reason for failure was considered due to the fact that when $\mathrm{K}_{0}$ was 0.5 or 0.6 , the applied horizontal stress did not provide required confining pressure that would have been in the field. It should be noted that these failures occurred under consolidated-undrained (or mostly undrained) conditions. If the ratio 


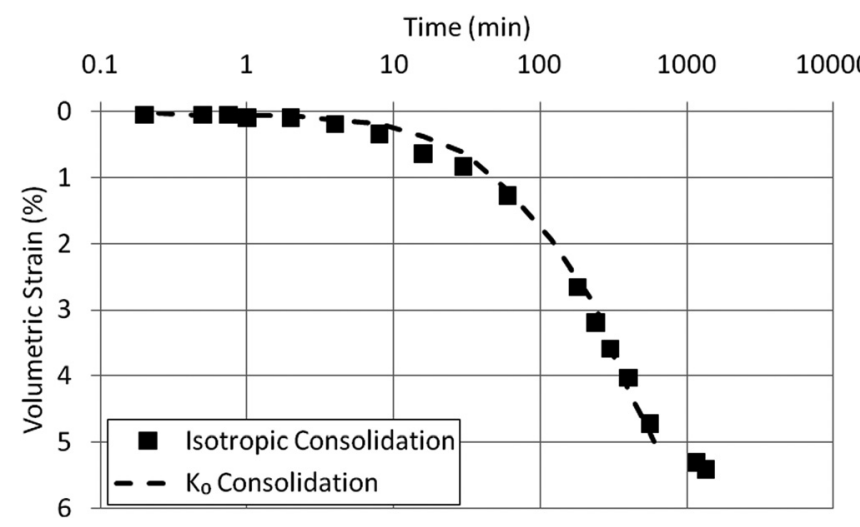

FIG. 5-Comparison of the $K_{0}$ consolidation curve with the isotropic consolidation curve.

of the undrained shear strength to the effective vertical stress (c/p ratio) of this soil is 0.25 , that would give a total stress friction angle $(\Phi)$ of $14^{\circ}$ giving an undrained active earth pressure coefficient $\left(\mathrm{K}_{\text {active }}\right)$ of 0.61 . If the shear-induced pore water pressures dissipated before the specimen failed, then the effective stress friction angle ( $\Phi^{\prime}$ ) would have been much higher (greater than 30 or even 40 degrees at these low normal stresses). Failure was not observed when $\mathrm{K}_{0}$ was 0.7 . Therefore it was assumed that the representative $\mathrm{K}_{0}$ of this soil was between 0.6 and 0.7 . Preliminary testing program showed that $\mathrm{K}_{0}$ of $0.5,0.6$, or 0.7 did not have a significant effect on the consolidation behavior (as can be seen later on in Fig. 6). In all latter tests, $\mathrm{K}_{0}$ of 0.7 was used.

Both the horizontal and vertical pressures felt by the specimen are directly related to the pore pressure distribution in the specimen. When an additional load is applied on the specimen, initially this load is carried by the pore fluid. This additional load is then transferred to the soil skeleton as the excess pore water pressure is dissipated. Therefore, when a constant cell pressure is applied to the specimen in a triaxial setup, the vertical pressure required to keep the $\mathrm{K}_{0}$ condition will increase proportional to the excess pore pressure dissipation. Therefore in all consolidation tests in the current study, the vertical pressures are applied incrementally to ensure the applied vertical stresses maintained the $\mathrm{K}_{0}$ equal to 0.7. The initial pore pressure dissipation curve was obtained from an isotropic consolidation test. In Fig. 5, the expected consolidation curve was labeled "Isotropic Consolidation." The curve " $\mathrm{K}_{0}$ Condition" indicates the volumetric strain changes when the verti-



FIG. 6-Summary of consolidation test results for water-saturated specimens.
TABLE 3-Comparison of measured rates of consolidation for water-saturated specimens.

\begin{tabular}{lcc}
\hline & \multicolumn{2}{c}{ Coefficient of Consolidation $\left(\mathrm{cm}^{2} / \mathrm{min}\right)$} \\
\cline { 2 - 3 } Effective Stress $(\mathrm{kPa})$ & Current Study & Mesri and Olson (1971) \\
\hline 10.3 & 0.07 & 0.07 \\
15.2 & 0.08 & 0.07 \\
\hline
\end{tabular}

cal load is applied following the pore pressure dissipation in the isotropic test. The figure shows that the observed consolidation behavior matches perfectly with the pore pressure dissipation during the consolidation stage.

\section{Results}

\section{Water-Saturated Specimens}

During the initial testing program, kaolinite was mixed with water only to prepare clean sediments samples. The lateral earth pressure coefficient $\left(\mathrm{K}_{0}\right)$ was varied to observe the effect on consolidation.

The void ratios versus effective stress relationships found in the current study for the clean sediments were similar to the results reported in Olson and Mesri (1970) for water-saturated specimens of kaolinite (Fig. 6). In addition, the depth of water above the sediment did not affect the results for water-saturated specimens since the effective stresses were the same (the curve labeled " $\mathrm{K}_{0}=0.7$ (I)" in Fig. 6 is for the stress condition where the mudline is $1.5 \mathrm{~m}$ below the water surface, while the curve labeled " $\mathrm{K}_{0}=0.7$ (II)" is for a $3 \mathrm{~m}$ water depth). It can also be concluded that there is no significant change in consolidation behavior for $\mathrm{K}_{0}$ of $0.5,0.6$, and 0.7 .

Mesri and Olson (1971) conducted hydraulic conductivity tests on water saturated kaolinite specimens. Coefficients of consolidation values were back-calculated by using the hydraulic conductivity values reported in their study. The coefficients of consolidation values found in this study were compared with Mesri and Olson (1971) in Table III.

\section{Oil and Water Saturated Specimens}

Six consolidation tests were performed at varying NAPL saturation ratios $\left(\mathrm{S}_{\mathrm{NAPL}}\right)$. $(15 \%$ to $100 \%)$. Oil-wetted specimens were prepared by mixing the kaolinite with oil first and then water. In water-wetted specimens, the opposite order of mixing was followed. Three of the specimens were prepared as water-wetted while the other three were oil-wetted. All the specimens were mixed to

TABLE 4-The properties of soil specimens tested.

\begin{tabular}{lccc}
\hline Test & Type & $\mathrm{S}_{\mathrm{NAPL}}$ & $\mathrm{C}_{\mathrm{c}}$ \\
\hline 1 & Oil-saturated & $100 \%$ & 0.41 \\
2 & Oil-wetted & $70 \%$ & 0.40 \\
3 & Water-wetted & $70 \%$ & 0.44 \\
4 & Oil-wetted & $42 \%$ & 0.56 \\
5 & Water-wetted & $39 \%$ & 0.47 \\
6 & Water-wetted & $15 \%$ & 0.56 \\
\hline
\end{tabular}




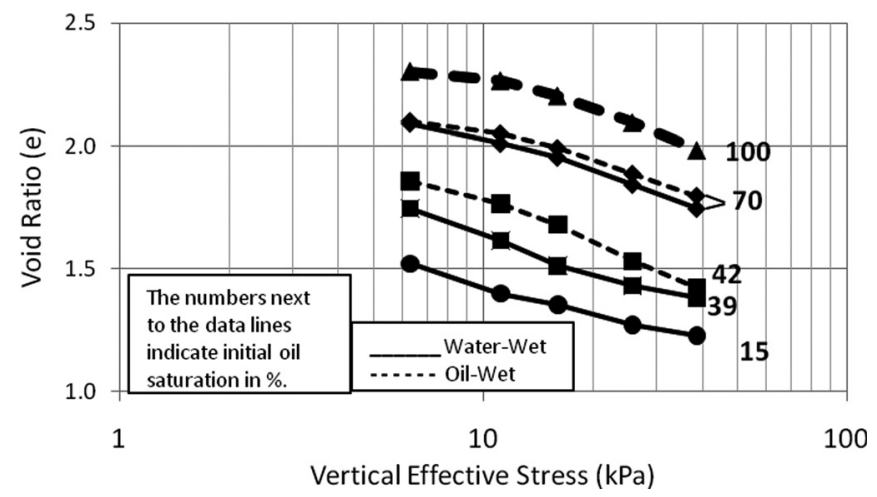

FIG. 7-Void ratio versus effective stress relation of the tested specimens.

$70 \%$ of $\mathrm{S}_{\mathrm{NAPL}}$ and compacted at a void ratio of 2.05 . The NAPL contents were then decreased to the desired values through water flushing as mentioned in the specimen preparation section. NAPL contents and compression indices $\left(\mathrm{C}_{\mathrm{c}}\right)$ of all the tests are given in Table IV. $\mathrm{C}_{\mathrm{c}}$ values varied between 0.40 and 0.56 .

Figure 7 shows void ratio versus vertical effective stress relations for all specimens. Due to the consolidation during the flushing stage, initial void ratios are lower when the desired initial NAPL saturation is lower due to longer flushing. While the compression index values vary with NAPL saturation ratios, they do not show significant differences. However, the general trend shows that sediments with higher $\mathrm{S}_{\mathrm{NAPL}}$, tend to be stiffer. In two tests where $\mathrm{S}_{\mathrm{NAPL}}$ is at $70 \%$, the consolidation behavior is very similar although one of the specimens is oil-wetted and the other is water-wetted. A similar conclusion can be made when the tests with $\mathrm{S}_{\mathrm{NAPL}}$ of $42 \%$ and $39 \%$ are compared. The results show that there is no significant difference in consolidation behavior between the oil-wetted and water wetted specimens.

Figure 8 shows the change in void ratio with increasing effective stress of tests conducted on water-wetted specimens where the initial $\mathrm{S}_{\mathrm{NAPL}}$ was below $35 \%$. In Figs. 8-11, the continuous line indicates that the expelling fluid during the consolidation stage is only NAPL, whereas the dashed line indicates that only water was expelled during the consolidation process.

Figure 9 shows how the $S_{\mathrm{NAPL}}$ changes with increasing vertical effective stress. As seen, when $\mathrm{S}_{\mathrm{NAPL}}$ reaches $18 \%$, the NAPL is no longer mobilized by changes in the confining pressure. The $\mathrm{S}_{\mathrm{NAPL}}$ indicates the ratio of volume of NAPL to the total volume

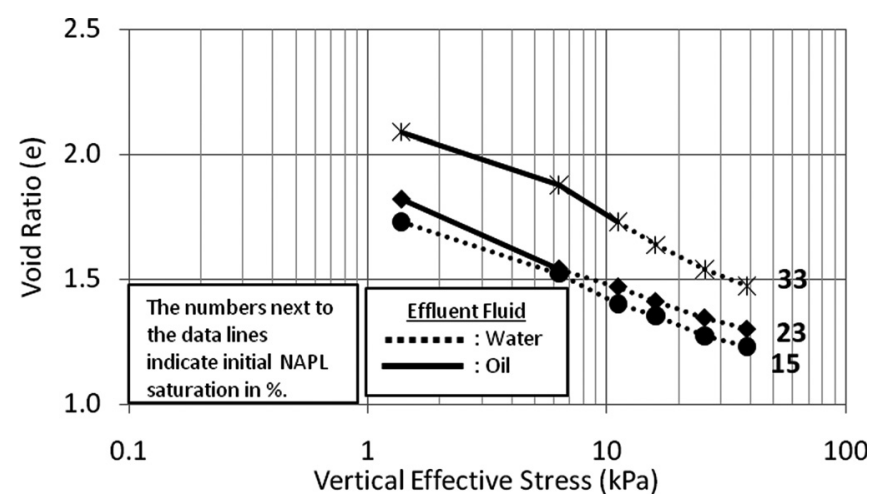

FIG. 8-Void ratio versus vertical effective stress curves for water-wetted specimens.

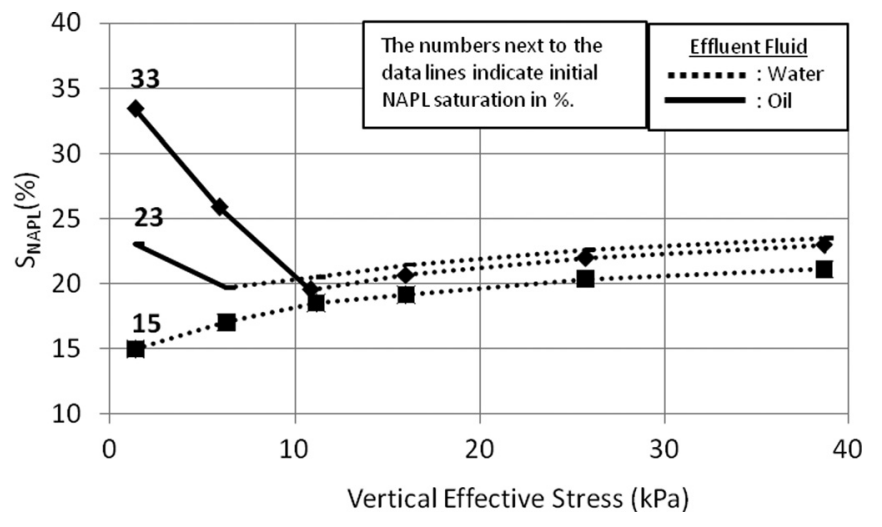

FIG. 9-Change in NAPL saturation during the test.

of the pore fluids and does not take into account the amount of soil solids. Therefore, a change in $\mathrm{S}_{\mathrm{NAPL}}$ is not a direct measure of the amount of retained oil in the sediment since the total volume of the pore fluid can be changing due to water expulsion, whereas $\theta_{\mathrm{NAPL}}$ includes the volume of both fluids as well as the volume of soil solids.

As seen in Fig. 10, the change in $\theta_{\text {NAPL }}$ shows a more characteristic trend when compared with the results in Fig. 9. Therefore, $\theta_{\mathrm{NAPL}}$ seems to provide a better way of quantifying the amount of residual NAPL. When $\theta_{\text {NAPL }}$ is around $12 \%$, the NAPL is no longer mobilized.



FIG. 10 - Change in volumetric NAPL content during the test.

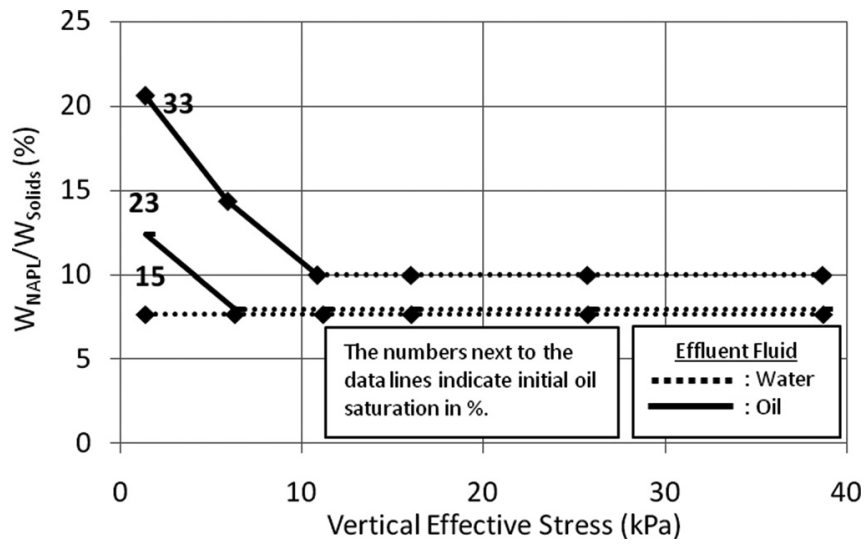

FIG. 11—Change in weight of NAPL per weight of soil solids. 
Figure 11 shows the change in the weight of NAPL $\left(\mathrm{W}_{\mathrm{NAPL}}\right)$ per weight of soil solids $\left(\mathrm{W}_{\text {Solids }}\right)$. The results indicate that when $\mathrm{W}_{\mathrm{NAPL}} / \mathrm{W}_{\text {Solids }}$ is between $8 \%$ and $10 \%$, NAPL in the soil matrix is immobilized.

\section{Summary and Conclusions}

In this study, a triaxial setup was implemented for testing the consolidation potential and resulting NAPL expulsion of soft, contaminated sediments. Several modifications were made to a conventional triaxial setup for consolidation testing under very low effective stresses. Bladder accumulators were used to collect the effluent for further analysis of the effluent.

A specimen preparation method was presented to prepare specimens at desired oil saturation ratios. Initial testing showed that the effect of $\mathrm{K}_{0}$ was observed to be negligible on void ratio versus effective stress relationship.

Six consolidation tests were conducted on a model soft sediment (kaolinite) at different oil saturation ratios. The results showed that $\mathrm{C}_{\mathrm{c}}$ values varied between 0.40 and 0.56 . When the NAPL content was higher, generally the soil was stiffer. The oil-wetted and waterwetted specimens showed similar consolidation behavior.

The results of tests with kaolinite, Soltrol 130 and water mixture showed that approximately $0.1 \mathrm{~g}$ of NAPL per $1 \mathrm{~g}$ of soil solids is unlikely to be mobilized by consolidation. The volume of NAPL above this retained residual can be used to design a containment system. Design of a capping system should be done only for the amount of the NAPL expected to be expelled. This will result in a thinner cap, and lesser amount of work will be required to place the cap material. The results showed that the proposed test setup and specimen preparation method was successful to evaluate the consolidation behavior of the model sediment.

\section{References}

Acar, Y. B., and I. Olivieri, 1989, "Pore Fluid Effects on the Fabric and Hydraulic Conductivity of Laboratory-Compacted Clay," Transp. Res. Rec., Vol. 1219, pp. 144-159.

ASTM D2216-10, 2010, "Standard Test Methods for Laboratory Determination of Water (Moisture) Content of Soil and Rock by Mass," ASTM, Philadelphia, PA.

Anandarajah, A., and D. Zhao, 2000, "Triaxial Behavior of Kaolinite in Different Pore Fluids," J. Geotech. Geoenviron. Eng., Vol. 126, No. 2, pp. 148-156.

Azcue, J. M., A. J. Zeman, A. Mudroch, F. Rosa, and T. Patterson, 1998, "Assessment of Sediment and Porewater After one Year of Subaqueous Capping of Contaminated Sediments in Hamilton Harbour, Canada," Water Sci. Technol., Vol. 37, No. 6-7, pp. 323-329.

El-Sherbiny, R. M., 2006, Performance of Suction Caisson Anchors in Normally Consolidated Clay, University of Texas, Austin, TX.
Imai, G., 1979, "Development of a New Consolidation Test Procedure Using Seepage Force," Soils Found., Vol. 19, No. 3, pp. 45-60.

Imai, G., K. Yano, and S. Aoki, 1984, “Applicability of Hydraulic Consolidation Test for Very Soft Clayey Soils," Soils Found., Vol. 24, No. 2, pp. 29-42.

Lee, J., and P. J. Fox, 2008, “An Experimental Investigation of Consolidation Induced Solute Transport," in GeoCongress 2008: Characterization, Monitoring, and Modeling of GeoSystems, ASCE, New Orleans, LA, pp. 806-813.

Lee, J., and P. J. Fox, 2009, "Investigation of ConsolidationInduced Solute Transport. II: Experimental and Numerical Results," J. Geotech. Geoenviron. Eng., Vol. 135, No. 9, pp. 1239-1253.

Lee, J., P. J. Fox, and J. J. Lenhart, 2009, “Investigation of Consolidation-Induced Solute Transport. I: Effect of Consolidation on Transport Parameters," J. Geotech. Geoenviron. Eng., Vol. 135, No. 9, pp. 1228-1238.

Ma, X., D. D. Reible, and M. Harris, 2010, “Assessment Feasibility of In-Situ Capping and Contaminant Mobility in NAPLContaminated Sediments," Int. J. Geotech. Eng., Vol. 4, No. 1, pp. 71-78.

Mesri, G., and R. E. Olson, 1971, "Mechanisms controlling the permeability of clays," Clays Clay Miner., Vol. 19, No. 3, pp. 151-158.

Moo-Young, H., T. Myers, B. Tardy, R. Ledbetter, W. VanaditEllis, and T. H. Kim, 2003, "Centrifuge simulation of the consolidation characteristics of capped marine sediment beds," Eng. Geol., Vol. 70, No. 3-4, pp. 249-258.

Moretti, L. K., 2008, Evaluation of Capping NAPL-Contaminated Sediment, Univ. of Texas, Austin, TX.

Olson, R. E., and G. Mesri, 1970, "Mechanisms Controlling Compressibility of Clays," ASCE J. Soil Mech. Found. Div., Vol. 96, No. 6, pp. 1863-1878.

Robinson, R. G., T. S. Tan, and F. H. Lee, 2003, “A comparative study of suction-induced seepage consolidation versus centrifuge consolidation," Geotech. Test. J., Vol. 26, No. 1, pp. 92-101.

Sridharan, A., and K. Prakash, 1999, "Simplified Seepage Consolidation Test for Soft Sediments," Geotech. Test. J., Vol. 22, No. 3, pp. 235-244.

Steward, K. K., 2007, Development of Apparatus and Method for Consolidating Very Soft, Contaminated Sediment, University of Texas, Austin, TX.

Thornley, D. M., W. B. Wilkinson, and A. Parker, 2006, "A preliminary investigation of the release of oil from contaminated clays and other fine-grained sediments during consolidation," Q. J. Eng. Geol. Hydrogeol., Vol. 39, No. 4, pp. 375-390.

U.S. Environmental Protection Agency, 1998, Method 3540-C: Soxhlet Extraction, Test Methods for Evaluating Solid Waste, Washington, D.C.

Zeman, A. J., 1994, "Subaqueous capping of very soft contaminated sediments," Can. Geotech. J., Vol. 31, No. 4, pp. $570-577$. 